\title{
Preface
}

Every book has its moment of birth. This book's moment was, perhaps, a few years ago, when a Jordanian-Palestinian friend of the authors finally managed to secure a visa for a short visit to Israel. These were memorable days. Together we explored the Old City of Jerusalem, walked along the seashore of Tel Aviv and visited the street in Jaffa from which our friend's grandmother had been forced to flee in 1948. For years our friend, a peace-loving Arab patriot and devout Muslim, had encountered Israel on a daily basis through the Jordanian and panArab media. Israel was so close geographically - yet so distant in all other respects; just as Jordan was for us, until our first visit there. For our friend, seeing Israel at first hand for the first time, some things were a disappointment, while others impressed him. We were intrigued to notice, for example, how astonished our friend was when he saw Arab Israelis on the boulevards of Tel Aviv. The experience forced us to reflect on a sad truth: given that so few Israelis visit Arab countries, and even fewer Arabs visit Israel, for most individuals on both sides of the borders the 'other' exists only as an imagined construct. In the Arab-Israeli conflict, the imagined is, in a sense, more real than any reality.

What follows is a study of Zionism and Israel as imagined entities in the writings of two ideological forces within Arab societies - Islamists and liberals. Starting with late nineteenth-century writings, but focusing primarily on the period from the Six Day War to the Arab Spring, this book explores how Arab Islamist and liberal ideologists and activists have treated one of the most remarkable and least predictable success stories of the twentieth century, which has also become one of the gravest tragedies of the Arab world, and of the Palestinian people in particular.

The book makes a comparative analysis of the relation between the political visions of Islamists and liberals and their conceptualizations of Zionism and Israel, exposing complex and nuanced views. Its main thesis is that the Zionist enterprise has played a dual function in the 
doctrines of both Arab Islamists and liberals: on the one hand, it is an enemy; on the other hand, a role model. As an enemy - or at the very least, an adversary - its victories on the battlefield and in the diplomatic arena have attested to the failures of Arab regimes and to the essentiality of embracing alternative worldviews. In Islamist thought the Zionist enterprise has been portrayed as a brutal, criminal and depraved rival, whose annihilation will be attainable only through the establishment of Islamic political orders; however, Islamists have also conceded that certain pragmatic provisional arrangements can be reached with Israel. The liberals are split between a 'peace camp' and a 'refusal camp'. The former, putting individual freedoms at the core of their agenda, have reached the conclusion that regardless of whether Zionism is legitimate, the realization of the liberal agenda requires a political compromise over Palestine; the latter, putting national independence at the core of their agenda, have stressed that only realization of the liberal agenda will allow Arabs to stand tall in the conflict against Zionism.

Another function of the Zionist enterprise in both Islamist and liberal thought has been that of a role model. The Zionist enterprise has been depicted as an 'other' that reflects values, methods of operation and institutions of which Arab societies should take heed. Islamists and liberals alike have discovered in Zionism and in Israeli society - or more precisely in Zionism and Israeli society as constructed by them to fit their specific agendas - qualities they have sought to implement in their own societies, whose shortcomings have been critically highlighted by interpretations of Zionist successes. Islamists have emphasized the religious (and more specifically religious-modern) essence of the Zionist movement, the cohesion and resourcefulness of Zionists, the meticulous plan that led to the establishment of the State of Israel, the Jewish diaspora's support of the Zionist enterprise and the similitude between Israeli democracy and the democracy that Islamists wish to establish in Arab societies. Liberals have emphasized the pluralistic nature of Israeli society, the freedom of expression enjoyed by its citizens, its strong relations with the West, the pragmatism of its leaders and its scientific, technological and economic accomplishments.

The duality of the Zionist enterprise in the doctrines of Arab Islamists and liberals is not unique, but characterizes their views of the West in general. As analysed throughout this book, Islamists describe the West as a vicious and corrupt 'other', but also as a representative of certain Islamic ideals that need to be re-embraced in Muslim societies, while liberals describe the West as both a liberator and a conqueror, an ideological reference and imperialistic threat at the same time.

Islamism and liberalism enjoyed little actual political clout in Arab 
states throughout most of the twentieth century. The liberals never regained their influence after their bitter, short-lived hegemony in the 1920s and the 1930s came to an end. Maintaining an outlook that was condemned and declined, they remained marginal and despondent. Islamists have grown stronger since the 1970s but nevertheless have failed in nearly every struggle to attain tangible power. Following the string of uprisings that began in late 2010 and were named the Arab Spring, the fortunes of these ideologies appeared to change, at least for a while. The revolutionary wave started with the tragic demonstration of Muhammad al-Bu'azizi, a 26-year-old street vendor from Sidi Bouzid in Tunisia, who, on 17 December 2010, set himself on fire in protest at the confiscation of his cart. Al-Bu'azizi's death ignited spontaneous mass protests that spread from Tunisia in a domino effect, especially to the republican-dynastic Arab regimes. The leaderships of Tunisia, Egypt, Libya and Yemen crumbled, while the Syrian regime was confronted by a colossal armed uprising. The liberal voice resonated loudly in the early days of the uprisings, yet, when first put to the electoral test, in Tunisia in October 2011 and in Egypt a month later, it was exposed as weak, divided and lacking any substantial popular base. Entering the arena of the Arab Spring at a later stage, Islamists won the first parliamentary elections in Tunisia and Egypt with a clear-cut, albeit not absolute, majority. In Tunisia, Islamists opted for national unity and consensus politics, and the newly established democratic regime in the country survived, though it remained fragile. In Egypt, Islamists also won the presidential race and a referendum on a new constitution, and sought to implement their agenda more rigorously. Their victories turned out to be a double-edged sword: in a military coup in July 2013, following mass demonstrations, they were desposed from power and their leaders were imprisoned. In elections held in Libya in July 2012, a coalition of relatively liberal movements - even though it was far from constituting a secular opposition - defeated the Islamists; the country remained unstable. In Yemen, the ousted president was succeeded by his deputy. As of late 2015, a transition to democracy was yet to occur. Predictions that liberal democracy - or the Islamist worldview - would sweep other Arab societies have thus far failed to materialize. The turbulent times of 2010-13 cannot be broadly defined as marking a rise - or rise and fall - of either Arab Islamism or Arab liberalism. It is in fact too early to define them in conclusive terms at all. Yet they have demonstrated that a plurality of worldviews competes for power in various Arab countries and have highlighted once again the importance of acquiring a deeper understanding of the contested ideological map of the Middle East. 
The book is divided into five chapters. The introductory chapter discusses the theoretical precariousness of the terms 'Arab Islamist' and 'Arab liberal' and offers definitions of these ideologies and a brief chronology of their development. It also presents the methodology and anthology used in the research. Chapter 1 discusses the formation of the Islamist approach toward Zionism and Israel. It explores the treatment of Israel as an illegitimate entity and an enemy that should be eradicated, the reasons for the development of an Islamist consensus around this position and the pragmatic adjustments made by Islamist leaders and organizations with regard to Israel. Chapter 2 discusses Islamist depictions of Zionism and Israel as role models and analyses the reasons for the formation and acceptance of such interpretations. Chapter 3 discusses the evolution of diverse liberal approaches to the legitimization of the Zionist enterprise, peace agreements with Israel and normalization with it, and sheds light on the reasons for disagreements on these issues within the liberal camp. Chapter 4 discusses liberal interpretations that represent Zionism and Israel as role models, and analyses the reasons for the formation and acceptance of such interpretations.

\section{Note on quotations}

In direct quotations, comments by the authors of this book are enclosed in square brackets. Some of the terminology used in the book is politically charged. Thus, for instance, one person's War of Independence is another's nakba, or disaster. We have made an effort to use terminology that coincides with the views of the authors discussed, even when the excerpts are not a direct quote. 
Uriya Shavit and ofir Winter - 9781526109439 Downloaded from manchesterhive.com at $04 / 26 / 2023$ 05:33:43AM via free access 